\title{
ROMANIA'S TAX SYSTEM: GOING BACKWARDS OR MOVING FORWARD?
}

\author{
Liviana Andreea Niminet \\ "Vasile Alecsandri" University of Bacau \\ liviananiminet@yahoo.com \\ Iulia Andreea Bucur \\ "Vasile Alecsandri" University of Bacau \\ iuliaandreea.bucur@gmail.com
}

\begin{abstract}
Having a tremendous importance for the modern state, tax system objectives, regulations and collection is a precise barometer for state's economic development and for its trajectory, as well as for more subtle aspects such as political efficiency and common weal. As we can easily understand it is essential that we know and comprehend the means and the endings of tax system in a dynamical sequence that means always looking at where it came from and, in the same time, where it is going to. It is for these reasons that we proposed a time evolution analyze for the Romanian tax system, highlighting its main components such as: personal income tax, corporate income tax, value added tax, social contributions, excise duty and the changes they have been through in the past years focusing on the current "fiscal revolution" and the alterations produced of Romania's tax system seen as a part of the European tax system.
\end{abstract}

\section{Keywords}

Tax system; European Union; Romania; contributions; regulation.

\section{JEL Classification}

$\mathrm{H} 20 ; \mathrm{H} 30$

\section{Introduction}

The importance of fiscal systems is unanimous recognized as a key factor that influence the entire economy. "The trend for saving, investment and working, influencing the increase of production and the decrease of unemployment, which represents an essential element of the economic strategy, making the fiscal reform an important component of the economic reform" (Postole, Ciobănaşu, 2013) is mainly if not solely determined by the fiscal system.

The state development determines a different tax and contribution level from one state to another. Inceu and Lazăr (2003) consider that the more economic developed countries by means of state budget and tax system reassign a more important part of Gross Domestic Product (GDP) than the less developed countries. Furthermore the structure and dimensions of the tax systems is so different from one country to another essentially because the needs of each country are unique.

\section{Actual state and data of taxing system in EU}

High levels of taxation in the EU, point out that this is an area with significant taxation and in the recent years is especially increasing. Furthermore, the fees' level in the European Union is not a novelty as it goes back since the latter part of the twentieth century. 
Taking into account that European countries have different levels of economic development, the major tax systems differences between countries can be easily explained.

It is important to note that we are still rather far from a unified approach to fiscal policy at European level, given that as long as there are both developed and developing countries, they have different economic levels, and thus, different economic needs. Some countries aimed at encouraging the private system and attracting new investments, either foreign or domestic, (emerging countries) and others aimed at "avoidance or reduction of tax evasion, maintaining existing market investors'" (Ciobănaşu, Priescu, Postole, Iliescu, 2009). Furthermore, taxes in the European Union increased significantly compared to other advanced economies, including major countries outside the EU, like members of the OECD.

Table 1 Current taxes on income, wealth, etc., \% of GDP. General government

\begin{tabular}{|c|c|c|c|c|c|c|c|c|c|c|c|c|}
\hline Time & geo 2006 & 2007 & 20082 & 2009 & 2010 & 2011 & 12012 & 220132 & 2014 & 42015 & 2016 & 2017 \\
\hline EU (28 countries) & 12.9 & 13.2 & 12.9 & 12.1 & 12.1 & 12.3 & 312.6 & 612.9 & 12.9 & 12.9 & $13^{(p)}$ & $13.2^{(p)}$ \\
\hline EU (27 countries) & 13 & 13.2 & 12.9 & 12.2 & 12.1 & 12.3 & 312.7 & 712.9 & 12.9 & 12.9 & $13^{(p)}$ & $13.2^{(p)}$ \\
\hline $\begin{array}{l}\text { Euro area (19 } \\
\text { countries) }\end{array}$ & 12 & 12.4 & 12.3 & 11.4 & 11.4 & 11.7 & 12.2 & 212.6 & 12.5 & 12.6 & $12.6^{(p)}$ & $12.9(p)$ \\
\hline $\begin{array}{l}\text { Euro area (18 } \\
\text { countries) }\end{array}$ & 12 & 12.4 & 12.3 & 11.5 & 11.4 & 11.7 & 12.3 & 312.6 & 12.6 & 12.6 & $12.6^{(p)}$ & $12.9^{(p)}$ \\
\hline Belgium & 16.1 & 15.9 & 16.1 & 14.9 & 15.3 & 15.8 & 316.1 & 16.7 & 16.8 & 16.6 & 16.3 & 16.8 \\
\hline Bulgaria & 4.6 & 7.2 & 5.8 & 5.3 & 4.8 & 4.6 & 4.7 & 5.1 & 5.4 & 5.4 & 5.6 & 5.9 \\
\hline Czech Republic & 8.6 & 8.8 & 7.8 & 7.1 & 6.8 & 7 & 6.9 & 7.2 & 7.3 & 7.2 & 7.6 & 7.7 \\
\hline Denmark & 28.8 & 28.6 & 27.9 & 28.3 & 28.5 & 28.4 & +29.2 & 230.23 & 33.2 & 30.6 & 30 & 30.1 \\
\hline Germany & 11.3 & 11.7 & 12 & 11.2 & 10.6 & 11.1 & 11.6 & $\begin{array}{ll}6 & 12 \\
\end{array}$ & 12.1 & 12.2 & 12.6 & 12.9 \\
\hline Estonia & 7 & 7.4 & 7.7 & 7.4 & 6.6 & 6.3 & 6.6 & 7.2 & 7.5 & 7.9 & 7.7 & 7.4 \\
\hline Ireland & 13.6 & 13.2 & 12.2 & 11.8 & 11.7 & 12.1 & 12.7 & 712.7 & 12.8 & 10.6 & 10.5 & 10.4 \\
\hline Greece & 8.3 & 8.3 & 8.1 & 8.5 & 8.3 & 9.2 & 10.8 & 310.5 & 9.7 & 9.7 & 10.4 & 10.2 \\
\hline Spain & 11.6 & 12.8 & 10.5 & 9.4 & 9.3 & 9.5 & 10.2 & 210.3 & 10.2 & 10.1 & 9.9 & 10.2 \\
\hline France & 11.8 & 11.7 & 11.9 & 10.7 & 11.2 & 11.7 & 12.4 & 412.9 & 12.7 & 12.7 & 12.6 & 12.9 \\
\hline Croatia & 6.8 & 7.3 & 7.1 & 7.1 & 6.6 & 6.4 & 6.3 & 6.5 & 6.3 & 6.1 & 6.6 & 6.3 \\
\hline Italy & 13.8 & 14.5 & 14.7 & 14.1 & 14.1 & 13.9 & 14.9 & 915 & 14.7 & 14.7 & 14.8 & 14.6 \\
\hline Cyprus & 9.2 & 11.9 & 11.1 & 9.6 & 9.4 & 10.1 & 9.9 & 10.3 & 10.3 & 9.9 & 9.6 & 9.6 \\
\hline Latvia & 7.9 & 8.3 & 9.1 & 7 & 7.4 & 7.3 & 7.7 & 7.7 & 7.8 & 7.9 & 8.4 & 8.6 \\
\hline Lithuania & 9.5 & 9.1 & 9.2 & 5.9 & 4.6 & 4.3 & 4.8 & 5 & 5 & 5.4 & 5.7 & 5.4 \\
\hline Luxembourg & 13 & 13.1 & 13.8 & 14.2 & 14.3 & 13.9 & 14.2 & 214.2 & 13.6 & 14.3 & 15.1 & 15.4 \\
\hline Hungary & 9.1 & 10 & 10.3 & 9.6 & 7.8 & 6.3 & 6.8 & 6.6 & 6.8 & 7 & 7.4 & 7.4 \\
\hline Malta & 11.3 & 12.6 & 12.1 & 13 & 12.2 & 12.4 & +13 & 13.7 & 13.7 & 13 & 13.6 & 14.1 \\
\hline Netherlands & 10.8 & 11.1 & 10.8 & 11 & 11.1 & 10.7 & 10.2 & 210.1 & 10.7 & 11.5 & $11.7^{(p)}$ & $12.8^{(p)}$ \\
\hline Austria & 12.8 & 13.2 & 13.8 & 12.6 & 12.7 & 12.8 & 313.1 & 13.4 & 13.7 & 14.2 & 13 & 13 \\
\hline Poland & 7.3 & 8.3 & 8.4 & 7.2 & 6.7 & 6.7 & 7 & 6.7 & 6.8 & 6.9 & 7.1 & 7.4 \\
\hline Portugal & 8.3 & 9.2 & 9.3 & 8.6 & 8.5 & 9.5 & 9 & 11.4 & 11 & 10.9 & 10.3 & 10.2 \\
\hline
\end{tabular}




\begin{tabular}{|l|c|c|c|c|c|c|c|c|c|c|c|c|}
\hline Romania & 6 & 6.5 & 6.4 & 6 & 5.8 & 6.1 & 5.8 & 5.9 & 6.2 & 6.6 & 6.5 & 6.1 \\
\hline Slovenia & 9 & 9 & 8.7 & 8.1 & 8 & 7.8 & 7.5 & 7 & 7.2 & 7.2 & 7.5 & 7.4 \\
\hline Slovakia & 6.4 & 6.4 & 6.7 & 5.8 & 5.6 & 5.7 & 5.8 & 6.4 & 6.8 & 7.3 & 7.3 & 7.1 \\
\hline Finland & 16.8 & 17 & 16.8 & 15.5 & 15.4 & 15.9 & 15.6 & 16.2 & 16.4 & 16.6 & 16.5 & 16.6 \\
\hline Sweden & 21.1 & 20.1 & 18.7 & 18.5 & 18.2 & 17.6 & 17.4 & 17.8 & 17.8 & 18.4 & 18.7 & 18.6 \\
\hline United Kingdom & 15.4 & 15.6 & 15.3 & 14.8 & 14.8 & 14.9 & 14.1 & 13.9 & 13.6 & 13.8 & 14.1 & 14.3 \\
\hline Iceland & 18.3 & 18.1 & 17.4 & 15.6 & 15.7 & 16.7 & 17 & 17.7 & 19 & 17.6 & 18 & 19.2 \\
\hline Liechtenstein & $:$ & $:$ & $:$ & $:$ & $:$ & $:$ & $:$ & $:$ & $:$ & $:$ & $:$ & $:$ \\
\hline Norway & 22.2 & 21 & 21.7 & 19.7 & 20.6 & 21.3 & 20.8 & 19 & 17.3 & 16 & 15.5 & 15.6 \\
\hline Switzerland & 13.9 & 13.9 & 14.3 & 14.4 & 14 & 14.1 & 14.1 & 14.2 & 14.1 & 14.8 & 15 & $:$ \\
\hline
\end{tabular}

Source of data: Eurostat, www.ec.europa.eu.

The table above highlights the dynamics of taxes in the past twelve years (from 2006) both in EU and EU member states, but also for some European, non EU states.

\section{Romanian Fiscal Code principles and realities}

Principles guiding the Romanian fiscal code are essential for the sanity of economic life and for this reason it is important that they are not only established, or written down, but also that they are the main reason behind any legislative action. Taxes covered by the Fiscal Code are based on the following principles: a) neutrality of tax measures in relation to the various categories of investors and capital, thereby ensuring a fair taxation level to the investors, both Romanian and foreigners; $b$ ) certainty of taxation by establishing clear legal provisions that do not lead to arbitrary interpretations, and the precise set of time, manner and amount of payment for each payer; c) justice and tax equity ensures that the tax burden of each taxpayer is determined on the basis of the contribution, depending on the amount of revenue or one's properties; d) tax efficiency provides similar levels of budget revenue from one year to another year by maintaining the efficiency of taxes and contributions in all phases of the economic cycle, both in times of economic boom and in the crisis; e)predictability refers to the stability taxations offers for periods of at least a year in which no changes could intervene regarding increasing or introduction of new forms of taxes and contributions.

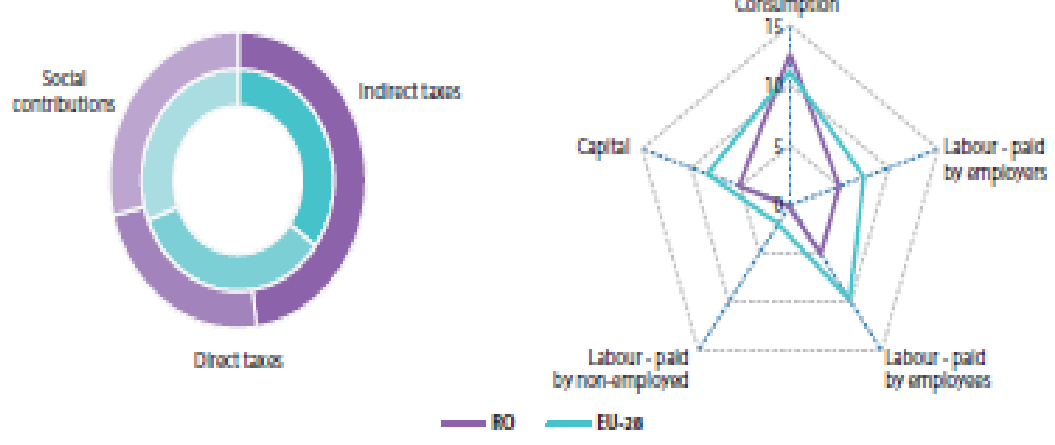

Figure 1 Tax revenues by main taxes, Romania compared to EU-28

Source: Taxation trends report, DG Taxation and Customs Union, 2017 
Although predictability is essential for the taxing system, Ordinance No 97/2017 deeply affects the provisions of the Fiscal Code as it entered into force on January 1st, 2018. The most important changes regard the following types of taxes: -social security contributions; - personal income tax; - microenterprises income tax; • corporate income tax; $\bullet$ VAT; $\bullet$ local taxes; $\bullet$ Excise duty.

As it follows we will take a closer look on the changes made to these types of taxes.

\section{Main categories of contributions}

The past few years amended the contribution framework. A synthetic overview of the main changes is presented below.

Table 2 Changes regarding social contributions

\begin{tabular}{|c|c|c|}
\hline $\begin{array}{l}\text { Change in the system of social contributions for the military, police and staff } \\
\text { of special penitentiaries. }\end{array}$ & N/A & $\begin{array}{l}\text { Legklation: } 27.07 .2015 \\
\text { In force from: } 01.01 .2016\end{array}$ \\
\hline $\begin{array}{l}\text { Increase in the ceiling for health insurance contributions for pension income } \\
\text { of RON } 740 \text { to an annual pension point value. }\end{array}$ & Base increase & $\begin{array}{l}\text { Legklation: } 0809.2015 \\
\text { In force from: } 01.01 .2016\end{array}$ \\
\hline $\begin{array}{l}\text { Introduction of a maximum ceiling for the monthly calculation base of } \\
\text { the social health insurance contributions. The maximum ceiling is } 5 \text { gross } \\
\text { average earnings. }\end{array}$ & Base decrease & $\begin{array}{l}\text { Legklation: 08.09.2015 } \\
\text { In force from: 01.01.2017 }\end{array}$ \\
\hline $\begin{array}{l}\text { The maximum ceiling for the monthly calculation base of the compulsory } \\
\text { contributions to the pension fund and to the health insurance fund has been } \\
\text { repealed. }\end{array}$ & Base increase & $\begin{array}{l}\text { Announcement: } 11.2016 \\
\text { Legklation: } 06.01 .2017 \\
\text { In force from: } 01.02 .2017\end{array}$ \\
\hline $\begin{array}{l}\text { People who obtain revenues from investment (dividends, interests) or/ } \\
\text { and other sources, and alongside these, obtain other revenues for which } \\
\text { they pay health contributions, such as salaries, pensions, revenues from } \\
\text { independent activities, revenues from rent, etc. will pay health contributions } \\
\text { for all these revenues. }\end{array}$ & Base increase & $\begin{array}{l}\text { Leglslation: } 08.09 .2015 \\
\text { In focce from: 01.01.2017 }\end{array}$ \\
\hline $\begin{array}{l}\text { Reintroduction of the exemption from health contributions of people } \\
\text { who obtain revenues from investment (dividends, interests) or/and other } \\
\text { sources, and, alongside these, obtain other revenues for which they pay } \\
\text { these contributions, such as salaries, pensions, revenues from independent } \\
\text { activities, revenues from rent, etc. }\end{array}$ & Base decrease & $\begin{array}{l}\text { Legklation: } 06.01 .2017 \\
\text { In force from: } 01.02 .2017\end{array}$ \\
\hline
\end{tabular}

Source: Taxation trends report, DG Taxation and Customs Union, 2017

Year 2018 brought important changes for CAS, CASS and CAM that cover the main categories of contributions, as follows: social security contribution (CAS) was established at the rate of $25 \%$ and is payable by individuals who have, as employees or other individuals, taxable incomes as defined by the Fiscal Code.. Health insurance contribution (CASS) at the rate of $10 \%$ is owed by the contributors from wages or other forms of income for which this contribution is due. This category is composed by a multitude of income sources such as dividend income, interest income, income from other sources, income from independent activities.

The first important change is that these revenues, excepted from the compulsory contributions to social health insurance before 2018, are now part of tax regulations, although the calculation method is slightly different as it is based on the minimum wage. Given these, a punctual analyze for each type of income is essential. Insurers' contribution to employment (CAM) at the rate of $2.25 \%$ is payable by employers from the gross wage fund. This contribution covers the risk and accident fund, unemployment fund, the fund for sick leave, wage claims guarantee fund. For arduous working conditions, employers pay a $4 \%$ from the gross wage fund contribution to social insurance and an $8 \%$ contribution for special working conditions. Shares of social security contributions of $25 \%$ and $10 \%$ for social health insurance are, starting 
from 2018, paid by employees but still retained by the employer from the gross wage, and also, the employer has the obligation of payment to the budget and submitting within the legal deadline (25th of the following month or 25th of the month following the quarter for the fiscal quarter period). In 2018 the wage calculation method is maintained meaning that from the gross income are withheld the social security contributions that are deductible for income tax and the tax base income is gross income reduced by social security and personal deductions.

A special feature for the social security contribution is the introduction of specific procedures for self-employment income from rental and leasing and dividends from other sources for which specific tax regimes are applied.

For example, if an individual is employed and also have income from dividends, they have to pay health insurance contribution both as an employee and on income from dividends. The monthly basis for calculating the contribution to health for the dividends income is the gross national minimum wage for the month in which the dividend is paid.

\section{Personal income tax}

Between 1990 and 2004 the personal income tax was based on progressive rates and from 2004 the flat rate tax scheme was adopted. Starting January 1, 2018, income tax was reduced from $16 \%$ to $10 \%$ for all categories of taxable income, excluding income from dividends that maintains rate of $5 \%$.

Table 3 Tax reforms before 2017. Personal income tax

\begin{tabular}{|c|c|c|}
\hline Description of measure & Change & Date \\
\hline \multicolumn{3}{|l|}{ Personal income tax: Earned Income } \\
\hline $\begin{array}{l}\text { Increase the amount of monthly exempt pension allowance from RON } 1000 \\
\text { to RON } 1050 \text {. }\end{array}$ & Base increase & $\begin{array}{l}\text { Legklation: 08.09.2015 } \\
\text { In force from: 01.01.2016 }\end{array}$ \\
\hline $\begin{array}{l}\text { For the monthly taxable income obtained from pensions : Increase the } \\
\text { amount of monthly exempt pension allowance from RON } 1050 \text { to RON } \\
2000 \text {, and pensioners are exempt from payment of social healthcare } \\
\text { contributions ( health contribution for pension income will be } \\
\text { acquitted from the state budget). }\end{array}$ & Base increase & $\begin{array}{l}\text { Announcement: 11.2016 } \\
\text { Legklation: 06.01.2017 } \\
\text { In force from: } 01.02 .2017\end{array}$ \\
\hline $\begin{array}{l}\text { Increase the personal deductions for individuals with a monthly income } \\
\text { below RON } 1500 \text {. }\end{array}$ & Base increase & $\begin{array}{l}\text { Legklation: 0809.2015 } \\
\text { In force from: 01.01.2016 }\end{array}$ \\
\hline Reduce the tax on dividends from $16 \%$ to $5 \%$. & Rate decrease & $\begin{array}{l}\text { Legklation: } 0809.2015 \\
\text { In force from: 01.01.2016 }\end{array}$ \\
\hline
\end{tabular}

Source: Taxation trends report, DG Taxation and Customs Union, 2017

An increase of personal deductions, was also established as follows: For individuals who have a gross monthly income of up to 1,950 lei, deductions are granted as follows: - for taxpayers who have no dependents $=510 \mathrm{lei} ; \bullet$ Taxpayers who have one dependent $=670 \mathrm{lei} ; \bullet$ taxpayers that have two dependents $=830$ lei; $\bullet$ taxpayers which have three dependents $=990$ lei; $\bullet$ Taxpayers with four or more dependents $=$ 1,310 lei.

For persons with a gross monthly wage between 1,951 lei and 3,600 lei the deductions are digressive to the above and for a gross monthly wage above 3,600 lei there are no personal deductions. The wage income tax is withheld by the employer, who is required to submit the declaration and the payment to the state budget. 


\section{Corporate tax and microenterprise (SMEs) income tax}

Starting 1990, the new framework regarding free initiative activities in industry, trade and services determined a progressive profit tax with rates from $1 \%$ up to $50 \%$. From 1991 until 1994 the law established 2 profit ratio: below 1,000,000 lei, a 30\% rate and above $1,000,000$, a $45 \%$ rate cumulated with temporary exonerations. From 1995 the tax rate was $38 \%$ and the temporary exonerations were eliminated. Starting 1997 the corporate tax system simplified gradually but it is still seen as one of the most inefficient forms of tax with very shallow collection rates (around 22\%).

To further simplify the tax system, in 2003 was introduced the microenterprise (SMEs) income tax.

Starting January 1st, 2018, a microenterprise income cap is 1,000,000 euros, calculated in lei at the rate of 31 December of the previous year. The tax rates of $1 \%$ for microenterprises that have at least a full-time employee and 3\% for microenterprises without employees are maintained. The conditioning to a field of activity is repealed meaning that companies which derive income from consulting and management in a percentage higher than $20 \%$ of total revenues, in the area of gambling, insurance, a.s.o. can also be microenterprises. The possibility to choose to pay corporate income tax by increasing the share capital to the amount of 45,000 lei is repealed.

The following Romanian legal entities cannot be microenterprises:

- Deposit Guarantee Fund in the banking system; • Investor Compensation Fund; • Guarantee Fund and private pension funds; • Guarantee private pension Fund; $\bullet$ tax transparent entity with legal personality.

If during the fiscal year a micro entity income exceeds one million euros, it will owe tax since the second quarter in which it exceeded the limit, and the calculation and payment of profit tax is made taking into account the revenues and expenditures from that quarter onward.

The following table contains the main changes on corporate income tax before 2018 .

Table 4 Corporate income tax. Reforms prior to 2018

\begin{tabular}{|c|c|c|}
\hline Corporate income tax & & \\
\hline $\begin{array}{l}\text { Increase of the turnover threshold for application of the micro-enterprise tax } \\
\text { regime from EUR } 65000 \text { to EUR } 100000 \text { euro per year and change in the tax } \\
\text { rate according to the number of employees }(1 \%, 2 \% \text { and } 3 \%) \text {. }\end{array}$ & Base increase & $\begin{array}{l}\text { Legklation: } 25.11 .2015 \\
\text { In force from: } 01.01 .2016\end{array}$ \\
\hline $\begin{array}{l}\text { The tax rate of } 1 \% \text { applies to all micro-enterprises with one or more } \\
\text { employees (previously, those with one employee applied a rate of } 2 \% 8 \text { ). } \\
\text { For micro-enterprises with no employees, the tax rate of } 3 \% \text { remains } \\
\text { unchanged. The condition regarding the income that a company must } \\
\text { obtain in order to be considered a micro-enterprise was changed. Thus, } \\
\text { revenues obtained by the company must not exceed the equivalent in Lei of } \\
\text { EUR } 500000 \text {. Previously, the limit had been set at EUR } 100000 \text {. }\end{array}$ & NA & $\begin{array}{l}\text { Legklation:06.01.2017 } \\
\text { In force from: } 01.02 .2017\end{array}$ \\
\hline
\end{tabular}

Source: Taxation trends report, DG Taxation and Customs Union, 2017

In 2018 is repealed the procedure on limited deductibility of interest expense on loans to other entities and to transpose the provisions of the Directive to limit the limited deductibility of interest expenses and other costs of debt to associated companies. Essentially, the interest charges on loans to associated companies are deductible in an amount of up to EUR 200,000. If the cost of borrowing exceeds $€$ 200,000 , then they are deductible in the $10 \%$ of the difference between revenues and expenses according to the accounting regulations, minus the non-taxable income and 
plus the profit tax expenses, the excess costs of debts and deductible amounts representing tax depreciation.

Another structural change in the income tax regulation is a more precise regulation of international transfer of assets from Romania to other states.

\section{Value Added tax}

In Europe, the history of Value Added Tax starts in France, back in 1954. By 1967 the member states of European Economic Community agreed to replace their own turnover tax with a common VAT. In Romania a 18\% VAT was first introduce in 1993 in order to replace the circulation of goods tax (which was into force from 1989 until 1992. Before 1989 Romania had a unique tax). VAT introduction meant inflation raise, but also stimulated investments and export. In 1998 VAT rate increased to $22 \%$ and from 2000 VAT rate decreased again to $19 \%$. Starting 2010 and until the end of 2015 the standard rate increased to $24 \%$. From January $1^{\text {st }} 2016$, VAT standard rate decreased again to $20 \%$ and from January $1^{\text {st }} 2017$ the standard rate was settled to $19 \%$ along with two reduced VAT rates of $9 \%$ and $5 \%$. A $18 \%$ rate as in 1993 was expected for 2018, but the "fiscal revolution" did not contained this VAT rate decrease after all.

The most important changes on VAT in the past three years are presented in table 5.

Table 5 VAT reforms before 2017

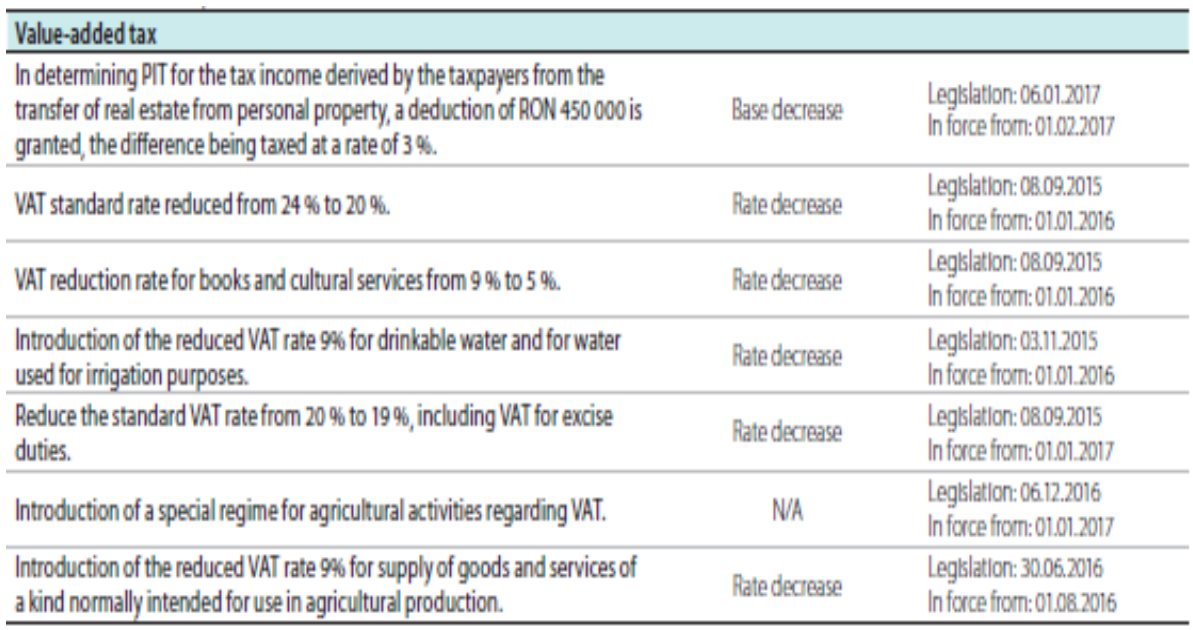

Source: Taxation trends report, DG Taxation and Customs Union, 2017

With the "fiscal revolution" of 2018, an anti-abuse rule was introduced on VAT deductibility. This is applicable when a taxable person procures goods or services from suppliers, which subsequently found to be involved in tax evasion. The tax authorities have the right to cancel the deduction of VAT on the company making the purchase, if they have evidence "beyond doubt" that the company knew or should have known that the supplier is involved in a case of VAT fraud. This new provision is transposing several European Court of Justice decisions, which established that the tax authorities may cancel the right to deduct VAT on purchases from suppliers with inappropriate fiscal behavior, unless proves undoubtedly that the taxable person is guilty of VAT fraud and the company that has deducted VAT from purchases knew or should have known that his supplier is involved in a case of VAT fraud. 


\section{Excise duties}

The main changes regarding excise duties as environmentally-related taxes concern:

Table 6 Excise duties changes

\begin{tabular}{|c|c|c|}
\hline Description of measure & Change & Date \\
\hline \multicolumn{3}{|l|}{ Environmentally-related taxes } \\
\hline Change in excise duty on akcoholic beverages. & Base increase & $\begin{array}{l}\text { Legislation: } 08.09 .2015 \\
\text { Inforce from: } 01.01 .2016\end{array}$ \\
\hline $\begin{array}{l}\text { Removal from the scope of excise duty of the excise on other goods (luxury } \\
\text { products, coffees) and the tax on crude oil from domestic production. }\end{array}$ & NA & $\begin{array}{l}\text { Legislation: } 08.09 .2015 \\
\text { Inforce from: } 01.01 .2016\end{array}$ \\
\hline Removal of the 7 cents excise duty & Pate decrease & $\begin{array}{l}\text { Legislation: } 08.09 .2015 \\
\text { Inforce from: } 01.01 .2017\end{array}$ \\
\hline $\begin{array}{l}\text { Increase in excise duty from RON } 430.71 \text { / } 1000 \text { cigarettes in } 2016 \text { to RON } \\
435.58 \text { / } 1000 \text { cigarettes. }\end{array}$ & Rate increase & $\begin{array}{l}\text { Legislation: } 08.09 .2015 \\
\text { In force from: } 01.01 .2017\end{array}$ \\
\hline
\end{tabular}

Source: Taxation trends report, DG Taxation and Customs Union, 2017

In the field of excise duties, in 2018 a new offense is introduced. All the equipment, tanks and containers in which are found products subject to excise duty (cigarettes and some alcoholic drinks) without being labeled or marked inadequately or by false marks will be seized. In addition to this seizure, a sanction consisting of a fine from 20,000 lei to 100,000 lei will also be applied.

\section{The predictable change}

Although at the very beginning or this article, when we presented the tax system principles we stated predictability, the "fiscal revolution" seemed to be not very well thought through, thus, on March 30, 2018, the Romanian government adopted a new emergency ordinance changing the Fiscal Code. Ordinance 25/2018 changed the Income tax for microenterprises, changes expected by an important part of this business field. It introduced the possibility of companies that now apply microenterprise income tax to opt only one time to switch from tax on microenterprises to corporate income tax only if those companies have a share capital of at least 45,000 lei and at least two full-time employees (can be employees with part- time work, but the duration of work cumulated must be equivalent to those of two full-time employees) employees with an employment contract for an indefinite period or at least two persons paid under contracts management or mandate an indemnity bigger than minimum wage. Switching to another tax system will be realized in the third quarter after the company satisfies the two conditions simultaneously, while calculating the tax will be made taking into account the revenues and expenses recorded on 1 of the first month of that quarter.

If after switching to a fiscal system, one or both conditions that allowed this switch is/are no longer met, then, to remain on the current system, the entity must meet the condition provided within 60 days. Otherwise it will switch over and will not be able to return to corporate tax unless it meets other criteria than those of equity or number of employees. In 2018 the opportunity to switch to microenterprise is viable only from the April 1, 2018 onward. Therefore all companies that meet the condition can switch the fiscal regime only from the second quarter. 


\section{Conclusions}

Romanian tax system has tried, in the past almost 30 years to find its path both within states borders as well as in the European Union, especially after 2007, when harmonization and adapting to European realities became a must. Nevertheless sometimes the regulations, rules and changes made to the Tax system and Fiscal Code seemed chaotic and no coherent, being subject to politically determinants rather than economic ones. 2018 came with a "fiscal revolution" that decreased income tax rate and moved social contributions solely on employee, following Flat Wage Level Law in public sector but bringing confusion and inequities both in the public as well as in the private sector, leaving the economic analysts with the question to what good was this "revolution" driven. The need to alter the new Fiscal Code with Emergency ordinances that counteract some of the flaws and inequities is, without a doubt, proof that either it was made for the wrong reasons or it was hustled and not well thought through without proper simulations and crossed analyzes that permit the foreseen effects within all components of Romanian economic system.

\section{References}

Ciobanasu, M., Priescu I., Postole, A., Iliescu, E. (2009), Tax avoidance for resident business by establishing offshore companies, Proceedings of the Fifth "Administration and Public Management" International Conference: "Public Institutions' Capacity to Implement the Administrative Reform Process", No. 23, Bucharest, June 23-24, 2009, Research Centre in Public Administration and Public Services, Bucharest, Romania

Inceu, A.M., Lazăr, D.T. (2003), Impozitul ca principal element al politicii fiscale, Revista Transilvană Științe Administrative, http://rtsa.ro/rtsa/index.php/rtsa/article/view/302/297

McGee, R. W. (2008) Taxation and Public Finance in Transition and Developing Economies, Springer Publishing House

Pătroi, D.P., Biriş, G. (2011) Controverse actuale în fiscalitate: comentarii şi soluţii, Bucharest, CH Beck

Postole, M. A., Ciobanasu, M. (2013), Role of custom duties in the formation of budget revenues, Journal of Knowledge Management, Economics and Information Technology, Issue 1/2013, p.203-2110

Emergency Ordinance of Romanian Government No 97/2017

Emergency Ordinance of Romanian Government No 25/2018

Taxation trends report (2017), DG Taxation and Customs Union, www.ec.europa.eu 